\title{
Pemaknaan Hidup Survivor Kanker Serviks selama Terapi Pengobatan: Literature Review
}

\author{
Regina Aprilia Roberto ${ }^{1 *}$, Wahyu Hidayati ${ }^{1}$ \\ ${ }^{1}$ Departemen Ilmu Keperawatan Fakultas Kedokteran, \\ Semarang, Indonesia \\ reginaapriliaroberto@gmail.com
}

\begin{abstract}
Introduction: Cervical cancer treatment process proves to make women experiencing emotional distress that brings new problems in life. Women with cervical cancer who undergo treatment suffer affecting all aspects of life that impact on the meaning of life. There is limited literature review regarding life meaning resources and technique used by women with cervical cancer who undergo treatment. The aim of this study is to find out description about the meaningfulness in life of cervical cancer survivor during treatment period based on sources and technique of finding meaning.

Methods: This study used literature review method. The literature search engines used are SCOPUS, SINTA and Google Scholar. The inclusion criteria of article were articles in Indonesian or English, containing sources and techniques for finding meaning in abstract, respondents cervical cancer survivor and published from 2011 to 2020.

Results: Eleven articles show the existence of meaning in life build upon sources of meaning in life including creative, experimental, attitudinal, and hopeful values. Moreover, there are techniques in seeking meaning involving self-understanding, positive action, familiarity with relationships, deepening the values of the meaning of life and worship.

Conclusion: The beginning of treatment process results feelings of meaningless, but efforts to make sense of life remain. Family support and spirituality were found to be the things that give the most meaning for cervical cancer survivors to survive.
\end{abstract}

Keywords: Cervical Cancer Survivor, Meaning in Life, Undergoing Treatment.

\begin{abstract}
Abstrak
Pendahuluan: Terapi kanker serviks menimbulkan tekanan emosional dan permasalahan baru. Wanita dengan kanker serviks mengalami penderitaan selama perawatan yang mempengaruhi semua aspek kehidupan yang berdampak pada makna hidup. Telaah literatur terkait sumber-sumber atau teknik yang digunakan survivor kanker serviks dalam memaknai hidup masih terbatas. Tujuan penelitian ini adalah menjelaskan sumber dan teknik pemaknaan hidup survivor kanker serviks selama menjalani terapi.

Metode: Penelitian ini menggunakan metode kajian literatur. Mesin pencarian literatur yang digunakan adalah SCOPUS, SINTA dan Google Scholar. Kriteria inklusi yang digunakan adalah artikel dengan Bahasa Indonesia atau Bahasa Inggris, mengandung sumber dan teknik menemukan makna pada abstrak, responden survivor kanker serviks dan terpublikasi sejak 2011 hingga 2020.

Hasil: Sebelas artikel terpilih menunjukkan keberadaan makna hidup berdasar sumber makna hidup yang meliputi creative values, experimental values, attitudinal values dan hopeful values dan teknik menemukan makna yang meliputi pemahaman diri, bertindak positif, pengakraban hubungan, pendalaman nilai-nilai makna hidup dan ibadah.

Kesimpulan: Permulaan proses pengobatan menghasilkan kondisi kehilangan makna, tetapi upaya untuk memaknai hidup tetap ada. Dukungan keluarga dan spiritualitas ditemukan menjadi hal yang paling memberikan makna bagi kehidupan survivor kanker serviks untuk bertahan hidup.
\end{abstract}

Kata kunci: Kebermaknaan Hidup, Survivor Kanker Serviks, Terapi Pengobatan. 


\section{PENDAHULUAN}

Kanker serviks menempati urutan ke-2 sebagai kejadian kasus kanker terbanyak dan penyebab kematian akibat kanker tersering di Indonesia. Sebanyak 32.469 wanita di Indonesia terdiagnosa mengidap kanker serviks dan sebesar 18.279 dari jumlah tersebut mengalami kematian (Bray, 2019; International Agency for Research on Cancer [IARC], 2019). Angka ketahanan hidup 5 tahun survivor kanker serviks pada tahun 2018 di Indonesia mencapai 84.201 (Bray, 2019).

Penatalaksanaan yang dijalani survivor kanker serviks terbukti dapat menimbulkan tekanan emosional (Yi \& Syrjala, 2017). Penelitian yang dilakukan terhadap 493 perempuan dengan kanker serviks menunjukkan permasalahanpermasalahan yang muncul selama menjalani terapi pengobatan seperti radioterapi, kemoterapi dan operasi. Permasalahan yang dilaporkan survivor diantaranya adalah gangguan emosional berupa kecemasan, depresi, nyeri, gangguan citra tubuh, perubahan berat badan, masalah perkemihan, gangguan seksual dan kurangnya informasi serta saran yang diperlukan (Duffy, 2015; Sitio, Suza, \& Nasution, 2016).

Proses pengobatan yang berpengaruh dan berdampak pada seluruh aspek kehidupan survivor kanker serviks dianggap sebagai sebuah penderitaan dan peristiwa tragis yang tidak dapat dielakkan (Bastaman, 2007). Survivor akan berupaya untuk mengatasinya dengan mengubah keadaan atau mengubah sikap dalam menghadapi keadaan yang tidak dapat diubah. Upaya yang dilakukan merupakan sebuah bentuk perjuangan hidup untuk memperoleh makna.
Kehidupan yang bermakna dikatakan sebagai hasrat mendasar dari setiap manusia. Hasrat untuk hidup bermakna mendorong setiap orang untuk melakukan berbagai kegiatan agar hidup memiliki arti. Terapi pengobatan merupakan upaya kegiatan yang dilakukan survivor kanker serviks untuk mendapatkan arti atau makna dari kehidupan. Makna hidup merupakan nilai yang dipegang dan diyakini seseorang dalam menjalani hidupnya. Situasi kehidupan atau kejadiankejadian yang dialami memiliki pengaruh terhadap perilaku individu. Kebermaknaan hidup dapat mengalami pergeseran bila seseorang mendapatkan masalah kesehatan (Bastaman, 2007).

Pemaknaan hidup yang dilakukan survivor kanker serviks akan berbeda dengan perempuan yang sehat secara fisik. Pemaknaan hidup tiap survivor kanker serviks juga dapat berbeda dengan satu sama lain dikarenakan sifat makna hidup itu sendiri yang unik, pribadi dan spesifik. Survivor kanker serviks mengungkapkan terjadinya perubahan peran dalam keluarga dan perubahan interaksi sosial. Perubahan peran menyebabkan kebutuhan untuk merasa berharga sebagai upaya mendapatkan arti atau makna hidup tidak tercapai. Interaksi sosial yang dibatasi hingga berkurang karena kanker serviks menyebabkan kebutuhan untuk mempengaruhi lingkungan sebagai bentuk untuk mencapai makna hidup tidak terealisasi (Sitio, Suza, \& Nasution, 2016). Penelitian lebih lanjut terkait sumbersumber atau teknik lain yang digunakan survivor kanker serviks perlu dilakukan untuk memaknai hidup. Perempuan yang mengalami kejadian kanker serviks menggambarkan hidup sebagai proses traumatis dan menganggap kanker serviks 
sebagai penderitaan yang menyakitkan, disaat bersamaan menghantarkan survivor kanker serviks dalam menemukan tujuan baru kehidupan dan menempatkan nilai lebih pada keluarga dan hal kecil yang membuat bahagia (Ochoa, Carillo, Sanabria, 2019).

\section{METODE}

Metode penelitian yang digunakan adalah kajian literatur. Data dikumpulkan secara online dengan search engine yaitu SCOPUS, SINTA dan Google Scholar.
Peneliti menerapkan pembatasan dalam pengumpulan data untuk menghindari bias dengan menentukan waktu publikasi yaitu sejak 2011-2020, tipe publikasi, responden, Bahasa Indonesia dan Bahasa Inggris, gender dan tipe file. Berdasarkan keyword yang telah ditentukan, didapatkan sebanyak 17.230 artikel pada search engine. Artikelartikel ini kemudian diseleksi kembali dengan kriteria inklusi hingga ditetapkan sebelas artikel yang terpilih untuk dianalisis dengan pendekatan meta-agregasi

\section{HASIL}

Diagram 1. Proses Pencarian Literatur

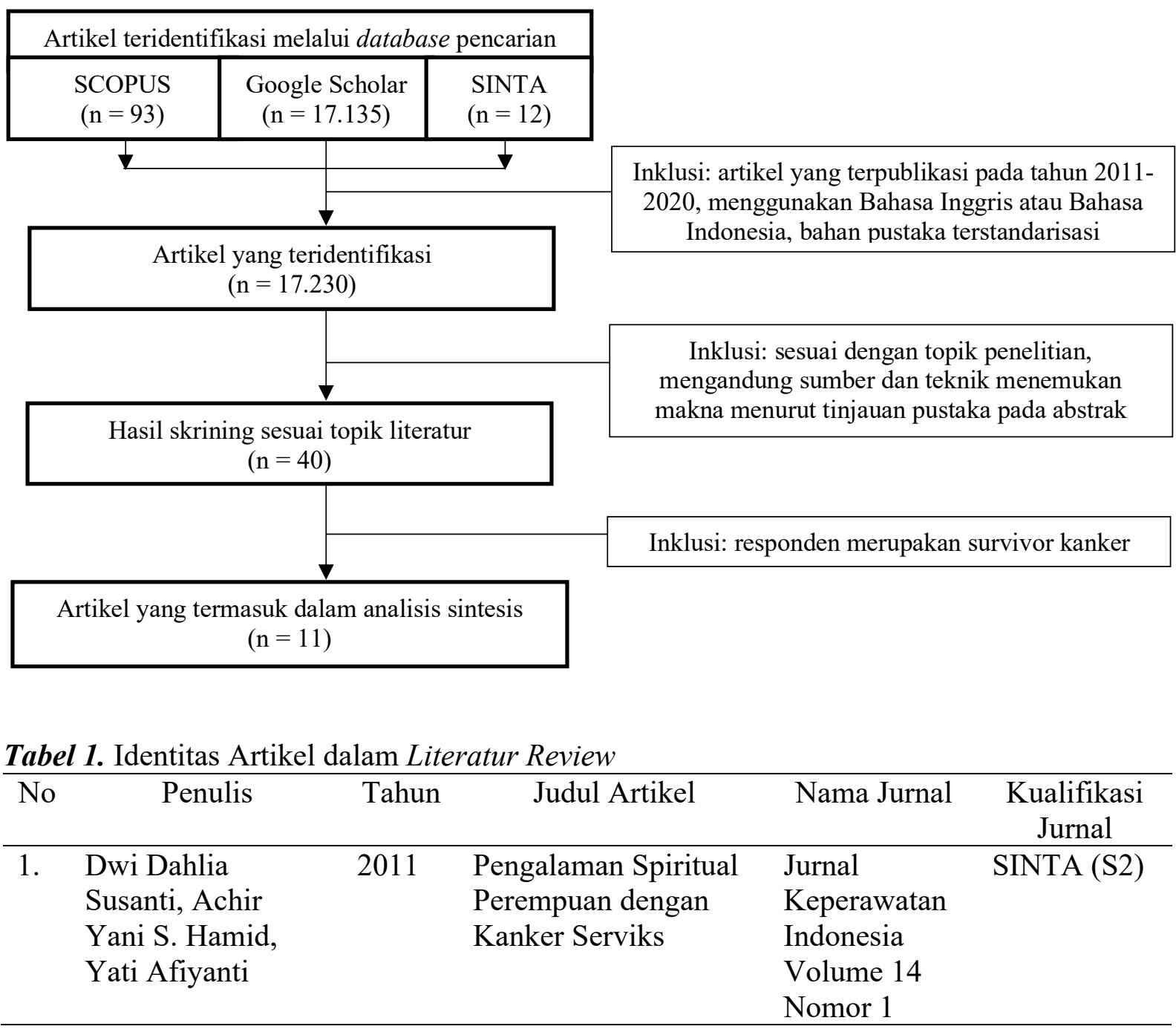

Tabel 1. Identitas Artikel dalam Literatur Review (lanjutan) 
Available Online at https://ejournal2.undip.ac.id/index.php/hnhs

\begin{tabular}{|c|c|c|c|c|c|}
\hline No & Penulis & Tahun & Judul Artikel & Nama Jurnal & $\begin{array}{c}\text { Kualifikasi } \\
\text { Jurnal }\end{array}$ \\
\hline 2. & $\begin{array}{l}\text { Nimas Ayu } \\
\text { Fitriana, Tri } \\
\text { Kurniati Ambarini }\end{array}$ & 2012 & $\begin{array}{l}\text { Kualitas Hidup Pada } \\
\text { Penderita Kanker } \\
\text { Serviks Yang } \\
\text { Menjalani Pengobatan } \\
\text { Radioterapi }\end{array}$ & $\begin{array}{l}\text { Jurnal } \\
\text { Psikologi } \\
\text { Klinis dan } \\
\text { Kesehatan } \\
\text { Mental } \\
\text { Volume } 1 \\
\text { Nomor } 3 \\
\end{array}$ & $\begin{array}{l}\text { Google } \\
\text { Scholar }\end{array}$ \\
\hline 3. & $\begin{array}{l}\text { Hiroko Komatsu, } \\
\text { Kaori Yagasaki, } \\
\text { Rie Shoda, } \\
\text { Younghui Chung, } \\
\text { Takashi Iwata, Juri } \\
\text { Sugiyama, Takuma } \\
\text { Fujii }\end{array}$ & 2014 & $\begin{array}{l}\text { Repair of the } \\
\text { Threatened Feminine } \\
\text { Identity: Experience } \\
\text { of Women With } \\
\text { Cervical Cancer } \\
\text { Undergoing Fertility } \\
\text { Preservation Surgery }\end{array}$ & $\begin{array}{l}\text { Cancer } \\
\text { Nursing } \\
\text { Volume } 37 \\
\text { Nomor } 1\end{array}$ & $\begin{array}{l}\text { SCOPUS } \\
\text { (Q1) }\end{array}$ \\
\hline 4. & $\begin{array}{l}\text { Yang Ding, Yan } \\
\text { Hu, Ingalill Rahm } \\
\text { Hallberg }\end{array}$ & 2015 & $\begin{array}{l}\text { Chinese Women } \\
\text { Living With Cervical } \\
\text { Cancer in the First } 3 \\
\text { Months After } \\
\text { Diagnosis }\end{array}$ & $\begin{array}{l}\text { Cancer } \\
\text { Nursing } \\
\text { Volume } 38 \\
\text { Nomor } 1\end{array}$ & $\begin{array}{l}\text { SCOPUS } \\
\text { (Q1) }\end{array}$ \\
\hline 5. & $\begin{array}{l}\text { Krista S. Pfaendler, } \\
\text { Lari Wenzel, } \\
\text { Mindy B. } \\
\text { Mechanic, Kristine } \\
\text { R. Penner } \\
\end{array}$ & 2015 & $\begin{array}{l}\text { Cervical Cancer } \\
\text { Survivorship: Long- } \\
\text { term Quality of Life } \\
\text { and Social Support }\end{array}$ & $\begin{array}{l}\text { Clinical } \\
\text { Therapeutics } \\
\text { Volume } 37 \\
\text { Nomor } 1\end{array}$ & $\begin{array}{l}\text { SCOPUS } \\
\text { (Q1) }\end{array}$ \\
\hline 6. & $\begin{array}{l}\text { Roma Sitio, Dewi } \\
\text { Elizadiani Suza, } \\
\text { Siti Saidah } \\
\text { Nasution }\end{array}$ & 2016 & $\begin{array}{l}\text { Kualitas Hidup Pasien } \\
\text { Kanker Serviks: } \\
\text { Pengalaman Pasien } \\
\text { Suku Batak Toba }\end{array}$ & $\begin{array}{l}\text { Idea Nursing } \\
\text { Journal } \\
\text { Volume } 7 \\
\text { Nomor } 1 \\
\end{array}$ & $\begin{array}{l}\text { Google } \\
\text { Scholar }\end{array}$ \\
\hline 7. & $\begin{array}{l}\text { Marloes Derks, } \\
\text { Luc R.C.W. van } \\
\text { Lonkhuijzen, } \\
\text { Rinske M. Bakker, } \\
\text { Anne M. } \\
\text { Stiggelbout, } \\
\text { Cornelis D. de } \\
\text { Kroon, Henrike } \\
\text { Westerveld, Jan } \\
\text { Paul W. R. } \\
\text { Roovers, Gemma } \\
\text { G. Kenter, Moniek } \\
\text { M. ter Kuile }\end{array}$ & 2017 & $\begin{array}{l}\text { Long-Term Morbidity } \\
\text { and Quality of Life in } \\
\text { Cervical Cancer } \\
\text { Survivors: A } \\
\text { Multicenter } \\
\text { Comparison Between } \\
\text { Surgery and } \\
\text { Radiotherapy as } \\
\text { Primary Treatment }\end{array}$ & $\begin{array}{l}\text { International } \\
\text { Journal of } \\
\text { Gynecological } \\
\text { Cancer } \\
\text { Volume } 27 \\
\text { Nomor } 2\end{array}$ & $\begin{array}{l}\text { SCOPUS } \\
\text { (Q2) }\end{array}$ \\
\hline
\end{tabular}


Tabel 1. Identitas Artikel dalam Literatur Review (lanjutan)

\begin{tabular}{|c|c|c|c|c|c|}
\hline No & Penulis & Tahun & Judul Artikel & Nama Jurnal & $\begin{array}{c}\text { Kualifikasi } \\
\text { Jurnal }\end{array}$ \\
\hline 8. & $\begin{array}{l}\text { Li-Rong Li, Mei- } \\
\text { Guang Lin, Juan } \\
\text { Liang, Qiong-Yan } \\
\text { Hu, Dan Chen, } \\
\text { Meng-Ying Lan, } \\
\text { Wu-Qing Liang, } \\
\text { Yu-Ting Zeng, } \\
\text { Ting Wang, Gui- } \\
\text { Fen Fu }\end{array}$ & 2017 & $\begin{array}{l}\text { Effects of Intrinsic } \\
\text { and Extrinsic Factors } \\
\text { on the Level of Hope } \\
\text { and Psychological } \\
\text { Health Status of } \\
\text { Patients with Cervical } \\
\text { Cancer during } \\
\text { Radiotherapy }\end{array}$ & $\begin{array}{l}\text { Medical } \\
\text { Science } \\
\text { Monitor } \\
\text { Volume } 23\end{array}$ & $\begin{array}{l}\text { SCOPUS } \\
\text { (Q2) }\end{array}$ \\
\hline 9. & $\begin{array}{l}\text { Rayi Dwi Vica } \\
\text { Shally, Juliani } \\
\text { Prasetyaningrum }\end{array}$ & 2017 & $\begin{array}{l}\text { Resiliensi pada } \\
\text { Penderita Kanker } \\
\text { Serviks Stadium } \\
\text { Lanjut }\end{array}$ & $\begin{array}{l}\text { Indigenous: } \\
\text { Jurnal Ilmiah } \\
\text { Psikologi } \\
\text { Volume } 2 \\
\text { Nomor } 1\end{array}$ & SINTA (S4) \\
\hline 10. & $\begin{array}{l}\text { Pichita Prasongvej, } \\
\text { Tongta } \\
\text { Nanthakomon, } \\
\text { Kankamol Jaisin, } \\
\text { Athita } \\
\text { Chanthasenanont, } \\
\text { Supapen } \\
\text { Lertvutivivat, } \\
\text { Chamnan } \\
\text { Tanprasertkul, } \\
\text { Kornkarn } \\
\text { Bhamarapravatana, } \\
\text { Komsun } \\
\text { Suwannarurk }\end{array}$ & 2017 & $\begin{array}{l}\text { Quality of Life in } \\
\text { Cervical Cancer } \\
\text { Survivors and Healthy } \\
\text { Women: Thai Urban } \\
\text { Population Study }\end{array}$ & $\begin{array}{l}\text { Asian Pacific } \\
\text { Journal of } \\
\text { Cancer } \\
\text { Prevention } \\
\text { Volume } 18\end{array}$ & $\begin{array}{l}\text { SCOPUS } \\
\text { (Q3) }\end{array}$ \\
\hline 11. & $\begin{array}{l}\text { Elizabeth Ochoa, } \\
\text { Gloria M. Carillo, } \\
\text { Daniel Sanabria }\end{array}$ & 2019 & $\begin{array}{l}\text { Finding myself as a } \\
\text { cervical cancer } \\
\text { survivor: A qualitative } \\
\text { study }\end{array}$ & $\begin{array}{l}\text { European } \\
\text { Journal of } \\
\text { Oncology } \\
\text { Nursing } \\
\text { Volume } 41\end{array}$ & $\begin{array}{l}\text { SCOPUS } \\
\text { (Q2) }\end{array}$ \\
\hline
\end{tabular}

Tabel 2. Ide Pokok dalam Literature Review

\begin{tabular}{|c|c|c|c|}
\hline $\mathrm{No}$ & Ide Pokok & Sub Topik Hasil & Referensi \\
\hline 1. & $\begin{array}{l}\text { Sumber-sumber } \\
\text { makna hidup }\end{array}$ & Creative values & $\begin{array}{l}\text { (Derks et al., 2017; Ding, Hu, \& Hallberg, } \\
\text { 2015; Li et al., 2017; Komatsu et al., 2014; } \\
\text { Ochoa, Carillo, Sanabria, 2019; Sitio, Suza, } \\
\text { \& Nasution, 2016; Rayi \& Juliani, 2017; } \\
\text { Susanti, Achir, \& Afiyanti, 2011) }\end{array}$ \\
\hline
\end{tabular}


Tabel 2. Ide Pokok dalam Literature Review (lanjutan)

\begin{tabular}{|c|c|c|c|}
\hline No & \multirow[t]{4}{*}{ Ide Pokok } & Sub Topik Hasil & Referensi \\
\hline & & Experimental values & $\begin{array}{l}\text { (Ding, Hu, \& Hallberg, 2015; Komatsu et } \\
\text { al., 2014; Nimas \& Kurniati, 2012; Ochoa, } \\
\text { Carillo, Sanabria, 2019; Pfaendler et al., } \\
\text { 2015; Prasongvej et al., 2017; Rayi \& } \\
\text { Juliani, 2017; Sitio, Suza, \& Nasution, 2016; } \\
\text { Susanti, Achir, \& Afiyanti, 2011) }\end{array}$ \\
\hline & & Attitudinal values & $\begin{array}{l}\text { (Nimas \& Kurniati, 2012; Rayi \& Juliani, } \\
\text { 2017) }\end{array}$ \\
\hline & & Hopeful values & $\begin{array}{l}\text { (Komatsu et al., 2014; Li et al 2017; Ochoa, } \\
\text { Carillo, Sanabria, 2019; Rayi \& Juliani, } \\
\text { 2017; Sitio, Suza, \& Nasution, 2016; } \\
\text { Susanti, Achir, \& Afiyanti, 2011) }\end{array}$ \\
\hline & \multirow[t]{5}{*}{$\begin{array}{l}\text { Teknik } \\
\text { Menemukan } \\
\text { Makna Hidup }\end{array}$} & Pemahaman diri & $\begin{array}{l}\text { (Ding, Hu, \& Hallberg, 2015; Komatsu et al, } \\
\text { 2014; Ochoa, Carillo, Sanabria, 2019; } \\
\text { Pfaendler et al., 2015; Rayi \& Juliani, 2017; } \\
\text { Susanti, Achir, \& Afiyanti, 2011) }\end{array}$ \\
\hline & & Bertindak positif & $\begin{array}{l}\text { (Ding, } \mathrm{Hu}, \& \text { Hallberg, 2015; Nimas \& } \\
\text { Kurniati, 2012; Ochoa, Carillo, Sanabria, } \\
\text { 2019; Rayi \& Juliani, 2017) }\end{array}$ \\
\hline & & $\begin{array}{l}\text { Pengakraban } \\
\text { hubungan }\end{array}$ & $\begin{array}{l}\text { (Ding, Hu, \& Hallberg, 2015; Komatsu et } \\
\text { al., 2014; Nimas \& Kurniati, 2012; Ochoa, } \\
\text { Carillo, Sanabria, 2019; Pfaendler et al., } \\
\text { 2015; Rayi \& Juliani, 2017; Susanti, Achir, } \\
\text { \& Afiyanti, 2011) }\end{array}$ \\
\hline & & $\begin{array}{l}\text { Pendalaman nilai- } \\
\text { nilai makna hidup }\end{array}$ & $\begin{array}{l}\text { (Li et al., 2017; Ochoa, Carillo, Sanabria, } \\
\text { 2019; Pfaendler et al., 2015; Prasongvej et } \\
\text { al., 2017; Rayi \& Juliani, 2017; Susanti, } \\
\text { Achir, \& Afiyanti, 2011) }\end{array}$ \\
\hline & & Ibadah & (Sitio, Suza, \& Nasution, 2016) \\
\hline
\end{tabular}

Berdasarkan Tabel 2, dapat diketahui bahwa semua artikel dalam kajian literatur menunjukkan adanya sumber-sumber makna hidup survivor kanker serviks selama menjalani terapi pengobatan yang meliputi creative, experimental, attitudinal dan hopeful values serta sepuluh dari sebelas artikel menunjukkan teknik-teknik menemukan makna hidup yang meliputi pemahaman diri, bertindak positif, pengakraban hubungan, pendalaman nilainilai makna hidup dan ibadah.

\section{PEMBAHASAN}

Pemenuhan hasrat dalam
menemukan makna hidup yang teraktualisasi menimbulkan kebahagiaan dalam hidup seseorang. Hidup yang ditemukan bermakna akan menciptakan pribadi penuh pengharapan dan mampu bertahan dalam situasi yang tak menyenangkan sekalipun. Hidup yang dihayati secara bermakna menimbulkan kepuasan dan kebahagiaan bagi orang yang 
menjalaninya. Seseorang dengan penghayatan hidup bermakna memiliki pemahaman yang baik untuk apa ia hidup dan bagaimana cara menjalani hidup. Pribadi yang mampu memaknai hidupnya dianggap sebagai gambaran kepribadian ideal (Bastaman, 2007).

Upaya untuk memberikan gambaran kebermaknaan hidup survivor kanker serviks selama menjalani pengobatan dilakukan peneliti dengan menggabungkan hasil kajian literatur dan teori kebermaknaan hidup menurut Bastaman. Proses pengobatan yang dianggap sebagai sebuah penderitaan bagi survivor kanker serviks, melahirkan kondisi kehilangan makna (Bastaman, 2007; Ochoa, Carillo, Sanabria, 2019). Kehidupan perempuan dengan kanker serviks dimulai dengan ketidakpastian dan kondisi sengsara sepanjang masa (Susanti, Achir, \& Afiyanti, 2011). Kesengsaraan yang dialami, tidak meruntuhkan upaya survivor kanker serviks untuk menemukan makna hidup. Hal ini ditunjukkan dari sumber-sumber dan teknik menemukan makna hidup yang muncul atau berubah selama menjalani pengobatan.

Sumber-sumber atau nilai-nilai yang dipercaya memungkinkan seseorang menemukan makna hidup diantaranya adalah creative values, experimental values, attitudinal values dan hopeful values (Bastaman, 2007). Nilai-nilai creative values yang ditunjukkan para survivor kanker serviks selama menjalani pengobatan adalah peran dalam keluarga dan kegiatan bekerja yang terhambat karena kondisi fisik. Peran dalam keluarga terganggu karena sebagai seorang ibu tidak dapat memenuhi tugas dan tanggung jawab (Ochoa, Carillo, Sanabria, 2019; Sitio, Suza, \& Nasution, 2016.)Perempuan yang belum menikah juga mengalami perubahan dalam creative values yang disebabkan oleh pertemuan dengan dokter ginekologis hingga jadwal terapi yang menggangu jam kerja. Krisis identitas juga dilaporkan terjadi pada perempuan yang baru terdiagnosa kanker serviks karena dihadapkan oleh situasi yang memaksa untuk menentukan jenis pengobatan yang tepat bila tetap ingin melahirkan anak. Kemampuan melahirkan anak dianggap sebagai komponen inti dari peran dan identitas seorang wanita (Susanti, Achir, \& Afiyanti, 2011).

Sumber lain yang memungkinkan seseorang menemukan makna hidupnya adalah experimental values yang muncul dan mengalami perubahan selama survivor kanker serviks menjalani terapi pengobatan adalah spiritualitas dan cinta kasih. Kompleks masalah yang dialami oleh individu yang menderita kanker serviks menyebabkan munculnya kebutuhan spiritual (Susanti, Achir, \& Afiyanti, 2011). Spiritualitas hadir sebagai koping yang membuat perempuan tetap menjalani pengobatan yang menyengsarakan (Ochoa, Carillo, Sanabria, 2019). Hal ini juga dirasakan oleh survivor kanker serviks Latina, kepercayaan akan Tuhan diungkapkan sebagai dukungan utama atau hal yang diandalkan selama masa pemulihan (Pfaendler et al., 2015). Nilai experimental lain yaitu cinta kasih juga tampak pada survivor kanker serviks selama masa pengobatan. Kasih sayang yang diberikan oleh suami, anak, kerabat hingga orang terdekat lainnya ditunjukkan melalui dukungan emosional dan motivasi untuk terus berjuang melawan penyakit (Ding, Hu, \& Hallberg, 2015; Pfaendler et al., 2015).

Attitudinal values yang nampak pada survivor kanker serviks selama 
menjalani pengobatan adalah sikap pasrah dan ikhlas dalam menerima keadaan yang terjadi. Penyakit yang diderita mendorong survivor kanker serviks untuk bersikap pasrah kepada Tuhan YME atas kondisi kesehatannya. Sikap pasrah juga dibersamai dengan nilai makna hidup lain yaitu hopeful values. Survivor pasrah akan perbuatan Tuhan atas kehidupannya, namun tetap memiliki harapan yang tinggi serta optimisme untuk sembuh sekalipun berada pada stadium lanjut (Prasongvej et al., 2017; Shally \& Prasetyaningrum, 2017). Rasa percaya diri survivor kanker serviks untuk sembuh dan harapan penuh akan masa depan juga terjadi pada pasien selama menjalani radioterapi, sekalipun menderita tekanan fisik dan psikologis (Li et al., 2017). Mayoritas partisipan dalam penelitian kualitas hidup survivor kanker serviks suku Batak Toba juga mengungkapkan harapannya untuk sembuh, punya anak lagi hingga keinginan untuk berumur panjang (Sitio, Suza, \& Nasution, 2016).

Sumber atau nilai yang berubah merupakan stimulus bagi survivor untuk mencari sumber baru dalam upaya pemaknaan hidup. Hal-hal yang sebelumnya diyakini membawa makna bagi kehidupan survivor kanker serviks dapat hilang selama menjalani pengobatan, namun dapat digantikan dengan sumber lain yang dirasa berharga. Penyesuaian diri dengan sumber yang ada juga akan mengubah teknik yang sebelumnya dilakukan dalam menemukan makna hidup.

Makna hidup dapat ditemukan dengan beberapa cara diantaranya pemahaman diri, bertindak positif, pengakraban hubungan, pendalaman nilainilai makna hidup dan ibadah. Survivor kanker serviks ditemukan telah berupaya melakukan cara-cara tersebut. Pemahaman diri dibuktikan dalam penyesuaian akan perubahan fisik, peran dan aktivitas seksual yang terjadi selama menjalani terapi pengobatan. Kebotakan, pembengkakan kelenjar, penurunan berat badan, konstipasi, mual, muntah hingga penurunan selera makan dialami oleh survivor kanker serviks dengan pengobatan operasi dan kemoradiasi (Sitio, Suza, \& Nasution, 2016; Pfaendler et al., 2015). Survivor mencoba memahami proses ketidaknyamanan yang ditimbulkan dari terapi pengobatan dengan berfokus pada kesembuhan.

Teknik menemukan makna hidup kedua adalah bertindak positif. Upaya bertindak positif dilakukan dengan cara bertahan dan meneruskan pengobatan yang dirasa menyiksa serta menimbulkan kesulitan keuangan. Survivor kanker serviks mencoba memikirkan hal-hal lain sebagai bentuk upaya distraksi. Hal-hal tersebut diantaranya adalah keinginan untuk melihat anaknya tumbuh besar, kegiatan yang menghibur hingga pekerjaanpekerjaan rumah yang dapat dilakukan (Ding et al., 2015; Fitriana \& Ambarini, 2012). Pengakraban hubungan yang juga diyakini sebagai teknik menemukan makna hidup juga terbukti pada survivor kanker serviks. Pengakraban hubungan atau peningkatan relasi serta kedekatan merupakan hal yang timbul dari rasa sayang yang diberikan oleh orang-orang terdekat (experimental values). Peningkatan hubungan antar keluarga dan pasangan ditunjukkan melalui bentuk perhatian dan dukungan moril, spiritual, motivasi dan informasi. Dukungan dan motivasi untuk menjalani pengobatan datang dari orangorang terdekat diantaranya anak, suami, anggota keluarga lainnya dan kerabat. 
Cara lain untuk menemukan makna hidup adalah dengan mendekatkan diri kepada Tuhan. Kegiatan beribadah merupakan realisasi dari nilai eksperimental yang sudah disebutkan sebelumnya. Spiritualitas dibuktikan meningkat pada survivor kanker serviks selama menjalani pengobatan. Frekuensi beribadah dikatakan menurun pada sebagian survivor kanker serviks namun mengalami peningkatan pada survivor dengan pengobatan radioterapi (Fitriana \& Ambarini, 2012; Susanti et al., 2011).

Teknik-teknik menemukan makna hidup survivor kanker serviks dilakukan berdasarkan sumber yang tersedia. Teknik menemukan makna merupakan respon dari sumber yang dipercayai menimbulkan makna bagi survivor kanker serviks selama masa pengobatan.

\section{KESIMPULAN DAN SARAN}

Hasil penelitian mengungkapkan bahwa survivor kanker serviks berhasil menemukan makna hidup selama menjalani pengobatan berdasarkan sumber dan teknik menemukan makna hidup yang tersedia. Permulaan proses pengobatan dianggap sebagai penderitaan dan menimbulkan kondisi kehilangan makna bagi survivor kanker serviks, tetapi upaya untuk memperoleh makna hidup tetap ada. Upaya untuk memperoleh makna ditunjukkan dari teknik menemukan makna hidup yang ada sebagai respon atas sumber-sumber makna hidup yang tersedia di kehidupan survivor kanker serviks selama masa pengobatan. Survivor kanker serviks berupaya untuk memaknai hidup dengan menyadari peran dan tanggung jawabnya dalam keluarga, mendekatkan diri pada Yang Maha Kuasa, bersikap pasrah dan berharap akan kesembuhan. Dukungan keluarga dan spiritualitas ditemukan menjadi hal yang paling memberikan makna bagi kehidupan survivor kanker serviks untuk bertahan hidup.

Saran bagi survivor kanker serviks untuk berperan aktif dalam upaya memaknai hidup selama menjalani pengobatan dengan menetapkan sumber dan menggunakan teknik-teknik yang dirasa sesuai. Bagi perawat untuk memberikan asuhan keperawatan holistik untuk membantu survivor kanker serviks selama menjalani pengobatan dalam memaknai hidupnya. Bagi peneliti selanjutnya disarankan untuk melakukan penelitian serupa secara kuantitatif agar dapat diketahui tingkat kebermaknaan hidup survivor kanker serviksselama masa pengobatan.

\section{DAFTAR PUSTAKA}

Bastaman, H. D. (2007). Logoterapi: Psikologi untuk Menemukan Makna Hidup dan Meraih Hidup Bermakna. Jakarta: PT. Raja Grafindo Persada.

Bray, F., Ferlay J., Soerjomataram, I., Siegel, R. L., Torre L. A., \& Jemal, A. (2019). Global cancer statistics 2018: GLOBOCAN estimates of incidence and mortality worldwide for 36 cancers in 185 countries. CA: $A$ Cancer Journal for Clinicians. 68(6), 394-424. doi: 10.3322/caac.21492

Cancer Council. (2017). Understanding cervical cancer: A guide for women with cancer, their families and friends (J. Mothoneos, ed.). Retrieved from foundationforwomenscancer.org/cervi calcancer

Derks, M., Van Lonkhuijzen, L. R. C. W., Bakker, R. M., Stiggelbout, A. M., De Kroon, C. D., Westerveld, H., Roovers, J. P. W. R., Kenter, G. G., \& Kuile, M. M. T. (2017). Long-term morbidity and quality of life in cervical 
cancer survivors: A multicenter comparison between surgery and radiotherapy as primary treatment. International Journal of Gynecological Cancer, 27(2), 350356.

10.1097/IGC.0000000000000880

Ding, Y., Hu, Y., \& Hallberg, I. R. (2015). Chinese women living with cervical cancer in the first 3 months after diagnosis: A qualitative study. Cancer Nursing, $\quad 38(1), \quad 71-80$. doi: 10.1097/NCC.0000000000000133

Duffy, S. (2015). Living with and beyond cervical cancer. London: Public Health England.

Fitriana, N. A., \& Ambarini, T. K. (2012). Kualitas hidup pada penderita kanker serviks yang menjalani pengobatan radioterapi. Jurnal Psikologi Klinis Dan Kesehatan Mental, 1(2), 123129.

IARC (International Agency for Research on Cancer). (2019). Human Papillomavirus and related cancers, fact sheet 2018. Diperoleh dari https://www.hpvworld.com/media/29/ media_section/4/2/1642/hpvworld090.pdf

Komatsu, H., Yagasaki, K., Shoda, R., Chung, Y., Iwata, T., Sugiyama, J., \& Fujii, T. (2014). Repair of the threatened feminine identity: Experience of women with cervical cancer undergoing fertility preservation surgery. Cancer Nursing, 37(1), 75-82. doi: 10.1097/NCC.0b013e3182888c13

Li, L. R., Lin, M. G., Liang, J., Hu, Q. Y., Chen, D., Lan, M. Y., ... Fu, G. F. (2017). Effects of intrinsic and extrinsic factors on the level of hope and psychological health status of patients with cervical cancer during radiotherapy. Medical Science Monitor, 23, 3508-3517. doi:
10.12659/MSM.901430

Ochoa, E., Carrillo, G. M., \& Sanabria, D. (2019). Finding myself as a cervical cancer survivor: A qualitative study. European Journal of Oncology Nursing, 41(45), 143-148. doi: 10.1016/j.ejon.2019.06.008

Pfaendler, K. S., Wenzel, L., Mechanic, M. B., \& Penner, K. R. (2015). Cervical cancer survivorship: Long-term quality of life and social support. Clinical Therapeutics, 37(1), 39-48. doi: 10.1016/j.clinthera.2014.11.013

Prasongvej, P., Nanthakomon, T., Jaisin, K., Chanthasenanont, A., Lertvutivivat, S., Tanprasertkul, C., ... Suwannarurk, K. (2017). Quality of life in cervical cancer survivors and healthy women: Thai urban population study. Asian Pacific Journal of Cancer Prevention, 18(2), 385-389. doi: 10.22034/APJCP.2017.18.2.385

Shally, R. D. V. Prasetyaningrum, J. (2017). Resiliensi pada penderita kanker serviks stadium lanjut. Jurnal Indigenous, 2(1), 77-86.

Sitio, R., Suza, D., \& Nasution, S. (2016). Kualitas hidup pasien kanker serviks: Pengalaman pasien Suku Batak Toba. Idea Nursing Journal, 7(1), 34-41.

Susanti, D. D., Hamid, A. Y. S., \& Afiyanti, Y. (2011). Pengalaman spiritual perempuan dengan kanker Serviks. Jurnal Keperawatan Indonesia, 14(1), 15-22. doi: 10.7454/jki.v14i1.52

Yi, J. C., \& Syrjala, K. L. (2017). Anxiety and depression in cancer survivors. Medical Clinics of North America, 101(6), 1099-1113. doi: 10.1016/j.mena.2017.06.005 